\title{
Analogues of the epoxy resin monomer diglycidyl ether of bisphenol F: Effects on contact allergenic potency and cytotoxicity
}

\author{
Niamh O'Boyle \\ Technological University Dublin, niamh.oboyle@tudublin.ie \\ Tamara Delaine \\ University of Goteborg \\ Kristina Luthman \\ University of Goteborg, luthman@chem.gu.se
}

See next page for additional authors

Follow this and additional works at: https://arrow.tudublin.ie/scschcpsart

Part of the Chemical Actions and Uses Commons, Environmental Health Commons, Organic Chemicals Commons, and the Toxicology Commons

\section{Recommended Citation}

O'Boyle, N. et al (2013). Analogues of the epoxy resin monomer diglycidyl ether of bisphenol F: Effects on cont. act allergenic potency and cytotoxicity. Chemical Research in Toxicology, 2012, 25(11) pp.

2469-2478.

This Article is brought to you for free and open access by the School of Chemical and Pharmaceutical Sciences at ARROW@TU Dublin. It has been accepted for inclusion in Articles by an authorized administrator of ARROW@TU Dublin. For more information, please contact arrow.admin@tudublin.ie, aisling.coyne@tudublin.ie, gerard.connolly@tudublin.ie.

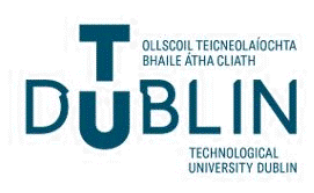




\section{Authors}

Niamh O'Boyle, Tamara Delaine, Kristina Luthman, Andreas Natsch, and Ann-Therese Karlberg

This article is available at ARROW@TU Dublin: https://arrow.tudublin.ie/scschcpsart/71 


\section{Final Draft of:}

Analogues of the epoxy resin monomer diglycidyl ether of bisphenol F: Effects on contact allergenic potency and cytotoxicity

Niamh M. O'Boyle*, Tamara Delaine, Kristina Luthman, Andreas Natsch, Ann-Therese Karlberg*

Chemical Research in Toxicology, 2012, Vol. 25, Issue 11, Pages 2469-2478

DOI: http://dx.doi.org/10.1021/tx300305k

\section{Analogues of the Epoxy Resin Monomer Diglycidyl Ether of Bisphenol F: Effects on Contact Allergenic Potency and Cytotoxicity}

Niamh O’Boyle $^{\dagger *}$, Tamara Delaine ${ }^{\dagger}$, Kristina Luthman ${ }^{\ddagger}$ Andreas Natsch ${ }^{\S}$, Ann-Therese Karlberg $^{* *}$

${ }^{\dagger}$ Department of Chemistry and Molecular Biology, Dermatochemistry and Skin Allergy, University of Gothenburg, SE-412 96 Gothenburg, Sweden

Department of Chemistry and Molecular Biology, Medicinal Chemistry, University of Gothenburg, SE-

41296 Gothenburg, Sweden

${ }^{\S}$ Givaudan Schweiz AG, Ueberlandstrasse 138, CH-8600 Duebendorf, Switzerland

*Corresponding authors. Email: oboyleni@tcd.ie; karlberg@chem.gu.se

Table of Contents Graphic

Diglycidyl ether of bisphenol F (DGEBF)

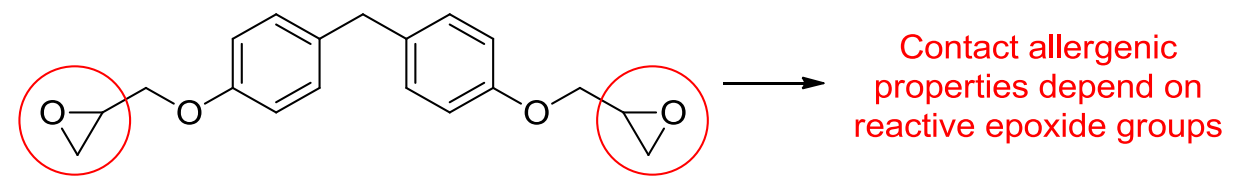

Cytotoxic properties depend both on reactive epoxide groups and other structural features 


\begin{abstract}
Diglycidyl ethers of bisphenol A (DGEBA) and bisphenol F (DGEBF) are widely used as components in epoxy resin thermosetting products. They are known to cause occupational and non-occupational allergic contact dermatitis. The aim of this study is to investigate analogues of DGEBF with regard to contact allergy and cytotoxicity. A comprehensive knowledge of the structural features that contribute to the allergenic and cytotoxic effects of DGEBF will guide the development of future novel epoxy resin systems with reduced health hazards for those coming into contact with them. It was found that the allergenic effects of DGEBF were dependent on its terminal epoxide groups. In contrast, it was found that the cytotoxicity in monolayer cell culture was not only dependent on the presence of epoxide groups, but also on other structural features.
\end{abstract}

\author{
Abbreviations \\ DGEBA Diglycidyl ether of bisphenol A \\ DGEBF Diglycidyl ether of bisphenol F \\ ERS Epoxy resin systems \\ IARC International Agency for Research on Cancer \\ LLNA Local lymph node assay \\ MTT 3-(4,5-Dimethylthiazol-2-yl)-2,5-diphenyltetrazolium bromide \\ $N$-ACME $\quad N$-Acetyl-L-cysteine methyl ester \\ PGE Phenyl glycidyl ether \\ $\operatorname{PPAR} \gamma \quad$ Peroxisome proliferator-activated receptor-gamma
}




\section{Introduction}

Epoxy resin systems (ERS) are commercial thermosetting products that are combinations of epoxy resins, curing agents, modifiers, and reactive diluents used in applications where strong, flexible, and light-weight construction materials are required. The global epoxy resin market is projected to reach over 3 million tons in annual sales by $2017 .{ }^{1}$ Examples of their uses are in paints, adhesives, coatings and electrical laminates. Due to their technical advantages, ERS continue to find new applications. Epoxy resin monomers are polymer precursor units which are reacted with hardeners to give the polymeric material. The most commonly used epoxy resin monomers are diglycidyl ethers based on bisphenol A (DGEBA) (also known as BADGE) and bisphenol $\mathrm{F}$ (DGEBF or BFDGE) (Figure 1). Alternatives to DGEBA and DGEBF are receiving commercial interest, as epoxy resins with a variety of properties are desired. ERS are often modified by the addition of reactive diluents, which are used mainly to reduce the viscosity and improve polymerization. Phenylglycidyl ether (PGE, Figure 1) is an example of a commonly used reactive diluent.

The main concerns with use of ERS at present are their environmental impact, their cytotoxicity and their ability to cause contact allergy. Epoxy resin monomers are among the most common causative agents of occupational contact dermatitis. ${ }^{2}$ Skin sensitization is known to be particularly common amongst construction workers and is caused by ERS present in cement and other building materials, ${ }^{3,4}$ but is also frequent in newer settings such as the production of wind turbine rotor blades ${ }^{5}$ and epoxy pipe relining. ${ }^{6}$ Epoxy resin monomers are also implicated in nonoccupational contact allergy. ${ }^{7} 8$ DGEBA is included in the European baseline series for diagnosis of contact allergy. ${ }^{9}$ ERS components other than the resin monomers have also been shown to be potent sensitizers. ${ }^{10}$ Allergic contact dermatitis from various epoxy resin system components ${ }^{6,11-}$ 
${ }^{18}$ including DGEBA and DGEBF ${ }^{5,19}$ has been reported. The skin sensitization potential has been investigated experimentally in vivo in mice and guinea pigs for DGEBA, ${ }^{20,}{ }^{21} \mathrm{DGEBF}^{21,}{ }^{22}$ PGE $^{23,}{ }^{24}$ and others. ${ }^{25}$ DGEBA, DGEBF and PGE are strong sensitizers in both species according to regulatory classifications. ${ }^{26}$

A number of ERS components have been demonstrated to be cytotoxic. PGE and resorcinol diglycidyl ether are classified by IARC as possibly carcinogenic to humans (class 2B). ${ }^{27}$ PGE is known to bind to and damage DNA in vitro. ${ }^{28}$ DNA damage, with sufficient dose and length of exposure, will trigger apoptosis and cytotoxicity. ${ }^{29}$ The genotoxicity of epoxides including PGE is known ${ }^{30}$ and PGE was suggested to be a direct-acting mutagen as long ago as $1979 .{ }^{31} \mathrm{~A}$ previous study of a series of six epoxides noted that diepoxide functionality and aromaticity increased the induction of apoptosis and cytotoxicity. ${ }^{29}$ It has been shown that DGEBA alkylates the isolated nucleophiles 4-(p-nitrobenzyl)-pyridine and deoxyguanosine. ${ }^{32}$ DGEBF is cytotoxic in the hepatoma cell line HepG2 ${ }^{33}$ and in intestinal Caco-2 cells. ${ }^{34}$ DGEBA was shown to be an antagonist of the nuclear transcription factor peroxisome proliferator-activated receptor-gamma $(\operatorname{PPAR} \gamma)$ in 3T3-L1 and 3T3-F442A preadipocytes. ${ }^{35}$ PPAR $\gamma$ inhibitors cause apoptosis and cell cycle arrest in colorectal carcinoma cells. ${ }^{36}$ In contrast, DGEBA acted as a PPAR $\gamma$ agonist in an ECV403 cell line. ${ }^{37}$ Further research demonstrated that DGEBA can also induce apoptosis independently of PPAR $\gamma$ in both caspase-dependent and independent manners. ${ }^{38,39}$

In this work we sought to investigate which structural features of DGEBF are important for its skin sensitizing potency. The in vivo murine local lymph node assay (LLNA) ${ }^{40}$ and the in vitro KeratinoSens $^{\mathrm{TM}}$ assay $^{41}$ were used to determine the sensitizing effects of the compounds. We also assessed the in vitro cytotoxicity of DGEBF analogues in the KeratinoSens ${ }^{\mathrm{TM}}$ cell line. The 
chemical reactivity was investigated using a model peptide and a model amino acid to estimate the possibility of binding to reactive residues in skin proteins.

\section{Experimental Procedures}

Caution: This study involves skin sensitizing compounds which must be handled with care.

Instrumentation and Mode of Analysis. ${ }^{1} \mathrm{H}$ and ${ }^{13} \mathrm{C}$ NMR spectroscopy was performed on a Jeol Eclipse 400 spectrometer at 400 and $100 \mathrm{MHz}$, respectively, using $\mathrm{CDCl}_{3}$ solutions (residual $\mathrm{CHCl}_{3} \delta 7.26$ and $\mathrm{CHCl}_{3} \delta 77.0$ as internal standards). Electron-ionization mass spectral analysis $(70 \mathrm{eV})$ was performed on a Hewlett-Packard 5973 mass spectrometer connected to a gas chromatograph (Hewlett-Packard 6890). The GC was equipped with a cool on-column capillary inlet and an HP-5MSi fused silica capillary column $(30 \mathrm{~m} \times 0.25 \mathrm{~mm}, 0.25 \mu \mathrm{m}$, Agilent Technologies, Palo Alto, CA). Helium was used as carrier gas, and the flow rate was 1.2 $\mathrm{mL} / \mathrm{min}$. The temperature program started at $70{ }^{\circ} \mathrm{C}$ for $1 \mathrm{~min}$, increased by $10{ }^{\circ} \mathrm{C} / \mathrm{min}$, and ended at $270{ }^{\circ} \mathrm{C}$ for $5 \mathrm{~min}$. For mass spectral analysis, the mass spectrometer was used in the scan mode detecting ions with $\mathrm{m} / \mathrm{z}$ values ranging from 50 to 1500 .

High performance liquid chromatography/mass spectrometry (LC/MS) analyses were performed using electrospray ionization (EIS) on a Hewlett-Packard 1100 HPLC/MS. The system included a vacuum degasser, a binary pump, an autoinjector, a column thermostat, a diode array detector, and a single quadrupole mass spectrometer. The HPLC was equipped with a HyPURITY C18 column $(150 \times 3 \mathrm{~mm}$ i. d., particle size $3 \mu \mathrm{m}$, Thermo Hypersil-Keystone, Thermo Electron Corp., Bellafonte, PA). The mobile phase consisted of $0.005 \%$ pentafluoropropanoic acid, $0.1 \%$ acetic acid, and 5\% acetonitrile in water (solvent A) and $0.005 \%$ pentafluoropropanoic acid, 
$0.1 \%$ acetic acid, and $50 \%$ water in acetonitrile (solvent B). A linear gradient from $0 \%$ to $100 \%$ B in $20 \mathrm{~min}$, followed by $10 \mathrm{~min}$ of isocratic elution was used. The flow rate was $0.40 \mathrm{~mL} / \mathrm{min}$ and the column temperature was set to $40{ }^{\circ} \mathrm{C}$. The electrospray interface was used with the following spray chamber settings: nebulizer pressure, $40 \mathrm{psig}$; capillary voltage, $3500 \mathrm{~V}$; drying gas temperature, $350^{\circ} \mathrm{C}$; and drying gas flow rate, $10 \mathrm{~L} / \mathrm{min}$. Fragmentor voltage was set to 120 V. The mass spectrometer was used in scan mode detecting molecular ions with $\mathrm{m} / \mathrm{z}$ values ranging from 50 to 2000 .

DGEBA, DGEBF, PGE and 3 (Figure 1) were purchased from Sigma-Aldrich; DGEBF was obtained as a mixture of three isomers. Resorcinol diglycidyl ether (3) was $91 \%$ pure when purchased and was further purified by column chromatography (hexane: ethyl acetate 7:3) prior to evaluation. Acetone was purchased from Merck (Darmstadt, Germany) and olive oil from Apoteket AB (Goteborg, Sweden). The peptide AcPHCKRM was purchased from Peptide 2.0 Inc. (Chantilly, USA). Unless otherwise indicated, reagents were obtained from commercial suppliers and used without further purification. TLC was performed using silica gel coated aluminium plates. The purity of both synthesized and purchased test compounds was $>98 \%$ (GC/MS) before evaluation in biochemical and biological assays.

\section{Chemical Synthesis}

\section{2-((4-(4-(2-Methoxyethoxy)benzyl)phenoxy)methyl)oxirane (1) (Scheme 1A).}

4-(2-Methoxyethoxy)benzoic acid (7): A solution of $\mathrm{KOH}(9.40 \mathrm{~g}, 166 \mathrm{mmol})$ in anhydrous ethanol $(85 \mathrm{~mL})$ was added to a solution of 4-hydroxybenzoic acid $(10.0 \mathrm{~g}, 72.4 \mathrm{mmol})$ in 
anhydrous ethanol $(115 \mathrm{~mL})$ under nitrogen atmosphere. The white suspension was stirred with dropwise addition of 2-bromo-1-methoxyethane $(8.84 \mathrm{~mL}, 13.0 \mathrm{~g}, 94.1 \mathrm{mmol})$. The reaction mixture was refluxed for $24 \mathrm{~h}$ under nitrogen atmosphere. A solution of $\mathrm{KOH}(8.25 \mathrm{~g}, 63.5$ mmol) in anhydrous ethanol $(75 \mathrm{~mL})$ was added and the reaction mixture was refluxed for a further $2 \mathrm{~h}$. After evaporation of the solvent, the residue was dissolved in water $(500 \mathrm{~mL})$ and acidified to $\mathrm{pH}=1$ with diluted $\mathrm{HCl}(1 \mathrm{~N})$. The precipitate was isolated by filtration, dried and purified by recrystallization in ethanol, to give $7(12.14 \mathrm{~g}, 86 \%)$ as white crystals. ${ }^{1} \mathrm{H}$ NMR $\delta$ $3.46(3 \mathrm{H}, \mathrm{s}), 3.78(2 \mathrm{H}, \mathrm{t}, \mathrm{J}=9.26 \mathrm{~Hz}), 4.19(2 \mathrm{H}, \mathrm{t}, \mathrm{J}=9.52 \mathrm{~Hz}), 6.97(2 \mathrm{H}, \mathrm{d}, \mathrm{J}=8.79 \mathrm{~Hz}) 8.05(2 \mathrm{H}$, d, J=8.79 Hz). ${ }^{13} \mathrm{C}$ NMR $\delta 59.3,67.4,70.7,114.3,121.8,132.3,163.2,171.3$. ESI-MS (70 eV), m/z (\%) 196 (66) (M+), 179 (2), 164 (1), 151 (6), 138 (13), 121 (33), 105 (6), 93 (5), 76 (6), 59 (100).

$N$-Methoxy-4-(2-methoxyethoxy)- $N$-methylbenzamide (8): $N$-Methylmorpholine $(2.8 \mathrm{~mL}$, $2.49 \mathrm{~g}, 25.4 \mathrm{mmol})$ was added dropwise to a solution of 7 (4.64 g, $23.7 \mathrm{mmol})$ in freshly distilled THF (35 mL) under nitrogen atmosphere. Isopropyl chloroformate $(27.8 \mathrm{~mL}, 26 \mathrm{mmol})$ was added dropwise at $-20{ }^{\circ} \mathrm{C}$ and the reaction mixture was stirred for 30 min at $-20{ }^{\circ} \mathrm{C}$. Freshly distilled triethylamine $(5.2 \mathrm{~mL}, 37.3 \mathrm{mmol})$ was added to a suspension of $\mathrm{N}, \mathrm{O}$ dimethylhydroxylamine hydrochloride (3.63 g, $37.6 \mathrm{mmol})$, in anhydrous DMF (20 mL). The suspension was added to the reaction mixture at $0{ }^{\circ} \mathrm{C}$. After 3.5 hours at $0{ }^{\circ} \mathrm{C}$, the reaction mixture was quenched with water $(300 \mathrm{~mL})$. The aqueous phase was extracted with ethyl acetate $(3 \times 100 \mathrm{~mL})$. The combined organic layers were washed with $\mathrm{HCl}(1 \mathrm{~N})(125 \mathrm{~mL})$, saturated aqueous $\mathrm{NaHCO}_{3}(125 \mathrm{~mL})$ and brine $(125 \mathrm{~mL})$ and were dried over anhydrous $\mathrm{Na}_{2} \mathrm{SO}_{4}$, filtered and concentrated in vacuo. The yellow oil was purified by column chromatography $\left(\mathrm{CH}_{3} \mathrm{OH}\right.$ : 
$\mathrm{CH}_{2} \mathrm{Cl}_{2}, 0.5$ : 99.5) $\left(\mathrm{R}_{\mathrm{f}}=0.32\right)$, to give $8(3.22 \mathrm{~g}, 57 \%)$ as a colorless oil. ${ }^{1} \mathrm{H}$ NMR $\delta 3.35(3 \mathrm{H}, \mathrm{s})$, $3.46(3 \mathrm{H}, \mathrm{s}), 3.55(3 \mathrm{H}, \mathrm{s}), 3.74-3.80(2 \mathrm{H}, \mathrm{m}), 4.13-4.18(2 \mathrm{H}, \mathrm{m}), 6.93(2 \mathrm{H}, \mathrm{d}, \mathrm{J}=8.79 \mathrm{~Hz}), 7.71$ $(2 \mathrm{H}, \mathrm{d}, \mathrm{J}=8.79 \mathrm{~Hz}) .{ }^{13} \mathrm{C}$ NMR $\delta 33.9,59.2,60.8,67.3,70.8,113.8,126.2,130.5,160.7,169.3$. ESI-MS (70 eV), m/z (\%) 239 (2) (M+), 209 (1), 179 (100), 135 (4), 121 (82), 104 (7), 93 (9), 76 (6), $59(20)$.

(4-tert-Butyldimethylsilyloxyphenyl)(4-(2-methoxyethoxy)phenyl)methanone (9): A solution of (4-bromophenoxy)-tert-butyldimethylsilane (97\%) $(5.02 \mathrm{~mL}, 5.92 \mathrm{~g}, 20 \mathrm{mmol})$ in freshly distilled THF (20.0 mL) under nitrogen atmosphere was stirred for $5 \mathrm{~min}$ and then cooled to -78 ${ }^{\circ} \mathrm{C}$. After stirring for a further $10 \mathrm{~min}, N$-butyllithium $(2.5 \mathrm{M}$ in hexanes) $(8.4 \mathrm{~mL}, 22 \mathrm{mmol}, 2$ equiv) was added dropwise to the solution. The temperature was kept at $-78{ }^{\circ} \mathrm{C}$ for 20 min, and then kept at $-40{ }^{\circ} \mathrm{C}$ for $40 \mathrm{~min}$. A solution of $\mathbf{8}(2.39 \mathrm{~g}, 10 \mathrm{mmol})$ in freshly distilled THF (15 $\mathrm{mL}$ ) was added dropwise to the in situ generated aryllithium under nitrogen atmosphere at -78 ${ }^{\circ} \mathrm{C}$. The temperature was kept at $-78{ }^{\circ} \mathrm{C}$ for $1 \mathrm{~h}$, then kept at $-30{ }^{\circ} \mathrm{C}$ for $40 \mathrm{~min}$ and then kept at room temperature for $1.5 \mathrm{~h}$. Aqueous $\mathrm{HCl}(1 \mathrm{~N})(13 \mathrm{~mL})$ was added and after $30 \mathrm{~min}$, the biphasic mixture was partitioned between chloroform $(30 \mathrm{~mL})$ and water $(50 \mathrm{~mL})$. The organic phase was washed with saturated, aqueous $\mathrm{NaHCO}_{3}(3 \times 100 \mathrm{~mL})$. The combined organic layers were dried with anhydrous $\mathrm{Na}_{2} \mathrm{SO}_{4}$ and concentrated in vacuo. The yellow oil was purified by column chromatography (hexane: ethyl acetate, 5:1) $\left(\mathrm{R}_{\mathrm{f}}=0.22\right)$, to give $9(3.66 \mathrm{~g}$, 95\%) as a colorless oil. ${ }^{1} \mathrm{H}$ NMR $\delta 0.25(6 \mathrm{H}, \mathrm{s}), 1.00(9 \mathrm{H}, \mathrm{s}), 3.47(3 \mathrm{H}, \mathrm{s}), 3.77-3.81(2 \mathrm{H}, \mathrm{m}), 4.18-4.22$ $(2 \mathrm{H}, \mathrm{m}), 6.89(2 \mathrm{H}, \mathrm{d}, \mathrm{J}=8.79 \mathrm{~Hz}), 6.98(2 \mathrm{H}, \mathrm{d}, \mathrm{J}=8.79 \mathrm{~Hz}), 7.72(2 \mathrm{H}, \mathrm{d}, \mathrm{J}=8.79 \mathrm{~Hz}), 7.78(2 \mathrm{H}, \mathrm{d}$, $\mathrm{J}=8.79 \mathrm{~Hz}) .{ }^{13} \mathrm{C}$ NMR $\delta-4.4,18.2,25.6,59.3,67.4,70.8,114.0,119.6,130.9,131.3,132.1$, 
132.2, 159.5, 162.0, 194.6. ESI-MS (70 eV), m/z (\%) 386 (100) (M+), 329 (99), 270 (21), 209 (91), 179 (68), $121(69)$.

1-tert-Butyldimethylsilyloxy-4-(4-(2-methoxyethoxy)benzyl)benzene (10): Solid zinc iodide (3.89 g, $12.2 \mathrm{mmol})$ and sodium cyanoborohydride (3.82 $\mathrm{g}, 60.9 \mathrm{mmol})$ were added to a solution of $9(3.14 \mathrm{~g}, 8.12 \mathrm{mmol})$ in 1,2-dichloroethane $(40 \mathrm{~mL})$ at room temperature. After $20 \mathrm{~h}$, the reaction mixture was filtered through Celite and the Celite was washed with $\mathrm{CH}_{2} \mathrm{Cl}_{2}$ The filtrate was concentrated in vacuo, to give $\mathbf{1 0}(3.01 \mathrm{~g}, 98 \%)$ as a colorless oil. ${ }^{1} \mathrm{H}$ NMR $\delta 0.17(6 \mathrm{H}, \mathrm{s})$, $0.97(9 \mathrm{H}, \mathrm{s}), 3.45(3 \mathrm{H}, \mathrm{s}), 3.72-3.77(2 \mathrm{H}, \mathrm{m}), 3.85(2 \mathrm{H}, \mathrm{s}), 4.08-4.12(2 \mathrm{H}, \mathrm{m}), 6.74(2 \mathrm{H}, \mathrm{d}$, $\mathrm{J}=8.42 \mathrm{~Hz}), 6.85(2 \mathrm{H}, \mathrm{d}, \mathrm{J}=8.42 \mathrm{~Hz}), 7.00(2 \mathrm{H}, \mathrm{d}, \mathrm{J}=8.42 \mathrm{~Hz}), 7.07(2 \mathrm{H}, \mathrm{d}, \mathrm{J}=8.42 \mathrm{~Hz}) .{ }^{13} \mathrm{C}$ NMR $\delta-4.5,18.2,25.7,40.2,59.2,67.2,71.0,114.5,119.9,129.6,129.7,133.9,134.2,153.8,157.0$. ESI-MS (70 eV), m/z (\%) 372 (87) (M+), 316 (19), 287 (6), 256 (13), 195 (100), 165 (18), 150 (8), 133 (29), 107 (19), 89 (25), 73 (6), 59 (14).

4-(4-(2-Methoxyethoxy)benzyl)phenol (11): A solution of tetra- $n$-butylammonium fluoride in THF $(1 \mathrm{M})(8.5 \mathrm{~mL}, 8.5 \mathrm{mmol})$ was added to a solution of $\mathbf{1 0}(3.0 \mathrm{~g}, 8.08 \mathrm{mmol})$ in freshly distilled THF $(33 \mathrm{~mL})$ under nitrogen atmosphere. After $3 \mathrm{~h}$ at room temperature, the reaction mixture was diluted with ethyl acetate $(75 \mathrm{~mL})$ and washed with a saturated solution of $\mathrm{NH}_{4} \mathrm{Cl}$ $(140 \mathrm{~mL})$. The aqueous layer was extracted with ethyl acetate $(3 \times 75 \mathrm{~mL})$. The combined organic layers were washed with water $(2 \times 175 \mathrm{~mL})$, brine $(175 \mathrm{~mL})$, dried over anhydrous $\mathrm{Na}_{2} \mathrm{SO}_{4}$ and concentrated in vacuo. The white crystals were purified by column chromatography $\left(\mathrm{CH}_{3} \mathrm{OH}\right.$ : toluene, 6:94) $\left(\mathrm{R}_{\mathrm{f}}=0.55\right)$, to give $11(1.87 \mathrm{~g}, 90 \%)$ as white crystals. ${ }^{1} \mathrm{H}$ NMR $\delta 3.45$ $(3 \mathrm{H}, \mathrm{s}), 3.75(2 \mathrm{H}, \mathrm{t}, \mathrm{J}=9.52 \mathrm{~Hz}), 3.84(2 \mathrm{H}, \mathrm{s}), 4.10(2 \mathrm{H}, \mathrm{t}, \mathrm{J}=9.52 \mathrm{~Hz}), 6.74(2 \mathrm{H}, \mathrm{d}, \mathrm{J}=8.06 \mathrm{~Hz})$, 
$6.84(2 \mathrm{H}, \mathrm{d}, \mathrm{J}=8.42 \mathrm{~Hz}), 7.02(2 \mathrm{H}, \mathrm{d}, \mathrm{J}=8.42 \mathrm{~Hz}), 7.06(2 \mathrm{H}, \mathrm{d}, \mathrm{J}=8.42 \mathrm{~Hz}) .{ }^{13} \mathrm{C}$ NMR $\delta 40.1$, 59.2, 67.2, 71.1, 114.6, 115.2, 129.7, 129.9, 133.7, 133.9, 153.8, 157.0. ESI-MS (70 eV), $m / z(\%)$ 258 (100) (M+), 199 (40), 183 (16), 165 (9), 152 (11), 107 (51), 94 (6), 77 (6), 59 (47).

2-((4-(4-(2-Methoxyethoxy)benzyl)phenoxy)methyl)oxirane (1): Epichlorohydrin (1.14 mL, $14.4 \mathrm{mmol})$ was added dropwise to a reaction mixture of $\mathbf{1 1}(0.92 \mathrm{~g}, 3.74 \mathrm{mmol})$ and $\mathrm{Cs}_{2} \mathrm{CO}_{3}$ $(2.34 \mathrm{~g}, 7.12 \mathrm{mmol})$ in freshly distilled acetonitrile $(60 \mathrm{~mL})$. The reaction mixture was refluxed for $3 \mathrm{~h}$ under nitrogen atmosphere. Water $(100 \mathrm{~mL})$ and ethyl acetate $(50 \mathrm{~mL})$ were added at room temperature and the separated water phase was extracted with ethyl acetate $(3 \times 60 \mathrm{~mL})$. The combined organic layers were washed with brine $(200 \mathrm{~mL})$, water $(200 \mathrm{~mL})$ and brine $(200$ $\mathrm{mL}$ ), dried over anhydrous $\mathrm{Na}_{2} \mathrm{SO}_{4}$ and concentrated in vacuo. The mixture was purified by column chromatography $\left(\mathrm{CH}_{3} \mathrm{OH}: \mathrm{CH}_{2} \mathrm{Cl}_{2}, 1: 99\right)\left(\mathrm{R}_{\mathrm{f}}=0.47\right)$ to give $\mathbf{1}(0.91 \mathrm{~g}, 78 \%)$ as white crystals. ${ }^{1} \mathrm{H}$ NMR $\delta 2.4(1 \mathrm{H}, \mathrm{dd}, \mathrm{J}=4.76,2.56 \mathrm{~Hz}), 2.89(1 \mathrm{H}, \mathrm{t}, \mathrm{J}=8.79 \mathrm{~Hz}), 3.31-3.37(1 \mathrm{H}, \mathrm{m})$, $3.44(3 \mathrm{H}, \mathrm{s}), 3.71-3.76(2 \mathrm{H}, \mathrm{m}), 3.86(2 \mathrm{H}, \mathrm{s}), 3.90-3.97(1 \mathrm{H}, \mathrm{m}), 4.06-4.12(3 \mathrm{H}, \mathrm{m}), 4.15-4.21$ (1H, m), 6.81-6.88 (4H, m), 7.04-7.11 (4H, m). ${ }^{13} \mathrm{C}$ NMR $\delta 40.1,44.7,50.1,59.2,67.2,68.8$, 71.0, 114.6, 129.7, 129.8, 133.8, 134.3, 156.8, 157.1. LC/MS (API-ES, $120 \mathrm{~V}) \mathrm{m} / \mathrm{z}(\%): 337.1$ $[\mathrm{M}+\mathrm{Na}](40), 332.1\left[\mathrm{M}+\mathrm{H}_{2} \mathrm{O}\right](100), 315.1[\mathrm{M}+\mathrm{H}](3), 165.1$ (58), 163.1 (51.5), 107.1 (9), 59.1 (8.3).

Bis(4-(2-methoxyethoxy)phenyl)methane (2) (Scheme 1B). A solution of potassium hydroxide $(0.74 \mathrm{~g}, 13.2 \mathrm{mmol})$ in anhydrous ethanol (ca $10 \mathrm{~mL}$ ) was added to a solution of 4,4'methylenediphenol (1.10 g, $5.5 \mathrm{mmol})$ in anhydrous ethanol. 2-Bromo-1-methoxyethane (1.34 $\mathrm{mL}, 14.3 \mathrm{mmol}$ ) was added and the reaction was refluxed for $4 \mathrm{~h}$. The solvent was evaporated 
and the residue was diluted with ethyl acetate $(70 \mathrm{~mL})$ and washed successively with $\mathrm{HCl}(1 \mathrm{M}$, $50 \mathrm{~mL}), \mathrm{NaOH}(2 \mathrm{M}, 50 \mathrm{~mL})$ and water $(50 \mathrm{~mL})$, and then dried over $\mathrm{Na}_{2} \mathrm{SO}_{4}$. The solvent was evaporated in vacuo. The product was purified by column chromatography $\left(\mathrm{CH}_{3} \mathrm{OH}: \mathrm{CH}_{2} \mathrm{Cl}_{2}\right.$, $0: 100$, then $0.25: 99.75$ then $0.5: 99.5)$ to give pure $2(0.50 \mathrm{~g}, 29 \%) .{ }^{1} \mathrm{H}$ NMR $\delta 3.43(6 \mathrm{H}, \mathrm{s}), 3.71$ $3.74(4 \mathrm{H}, \mathrm{m}), 3.85(2 \mathrm{H}, \mathrm{s}), 4.07-4.09(4 \mathrm{H}, \mathrm{m}), 6.83(4 \mathrm{H}, \mathrm{d}, \mathrm{J}=6.6 \mathrm{~Hz}), 7.96(4 \mathrm{H}, \mathrm{d}, \mathrm{J}=8.8 \mathrm{~Hz})$. ${ }^{13} \mathrm{C}$ NMR $\delta 40.2,59.3,67.3,71.2,114.6,123.8,134.0,157.2$. ESI-MS $(70 \mathrm{eV}) \mathrm{m} / z(\%) 316(100)$ (M+), 257 (18), 207 (34), 199 (19), 107 (19), 59 (66).

(2-Methoxyethoxy)benzene (4) (Scheme 1C). A solution of KOH (12 mmol) in dry ethanol (5 $\mathrm{mL})$ was added to phenol $(0.49 \mathrm{~g}, 5.3 \mathrm{mmol})$ in dry ethanol $(5 \mathrm{~mL})$. 2-Bromo-1-methoxyethane (0.65 $\mathrm{mL}, 6.9 \mathrm{mmol})$ was added and the reaction was refluxed for $4 \mathrm{~h}$. The solvent was evaporated and the residue was dissolved in ethyl acetate $(70 \mathrm{~mL})$. The organic layer was washed successively with $\mathrm{HCl}(1 \mathrm{M}, 50 \mathrm{~mL}), \mathrm{NaOH}(2 \mathrm{M}, 50 \mathrm{~mL})$ and water $(50 \mathrm{~mL})$ and was dried over $\mathrm{Na}_{2} \mathrm{SO}_{4}$. The solvent was evaporated in vacuo. The product was purified by column chromatography (hexane: ethyl acetate 9:1) to yield $4(0.22 \mathrm{~g}, 27 \%) .{ }^{1} \mathrm{H}$ NMR $\delta 3.45(3 \mathrm{H}, \mathrm{s})$, $3.73-3.76(2 \mathrm{H}, \mathrm{m}), 4.11-4.13(2 \mathrm{H}, \mathrm{m}), 6.93-6.95(3 \mathrm{H}, \mathrm{m}), 7.26-7.30(2 \mathrm{H}, \mathrm{m}) .{ }^{13} \mathrm{C} \mathrm{NMR} \delta 59.3$, 67.2, 71.1, 114.7, 120.9, 129.5, 158.8. ESI-MS (70eV) m/z (\%) 152 (61) (M+), 107 (11), 94 (55), 77 (51), 65 (17), 59 (100), 51 (17).

\section{1,5-Bis(2,3-epoxypropoxy)pentane (5) (Scheme 2).}

1,5-Bis(allyloxy)pentane (12): Sodium hydride (0.62 g, $26 \mathrm{mmol}, 5.2$ equiv) was washed with hexane $(20 \mathrm{~mL} \times 2)$, suspended in anhydrous THF $(40 \mathrm{~mL})$ and cooled to $0{ }^{\circ} \mathrm{C}$. Pentane-1,5-diol (0.52 $\mathrm{g}, 5.0 \mathrm{mmol})$ was dissolved in anhydrous THF $(20 \mathrm{~mL})$ and added to the suspension. The 
mixture was stirred at $0{ }^{\circ} \mathrm{C}$ for $10 \mathrm{~min}$. Allyl bromide $(1.12 \mathrm{~mL}, 13 \mathrm{mmol}, 2.6$ equiv) was added and the mixture was stirred at room temperature for $90 \mathrm{~min}$ before refluxing overnight. The reaction was continued until TLC indicated disappearance of the starting material. The mixture was cooled to $0{ }^{\circ} \mathrm{C}$ and saturated aqueous $\mathrm{NH}_{4} \mathrm{Cl}(70 \mathrm{~mL})$ was added slowly to quench the reaction. The aqueous layer was extracted with ethyl acetate $(70 \mathrm{~mL} \times 3)$. The combined organic fractions were washed with brine $(150 \mathrm{~mL})$, dried over anhydrous $\mathrm{Na}_{2} \mathrm{SO}_{4}$ and reduced in vacuo. Compound 12 was obtained as a colorless oil $(0.70 \mathrm{~g}, 76 \%) .{ }^{1} \mathrm{H}$ NMR $\delta 1.35-1.41(\mathrm{~m}, 2 \mathrm{H}), 1.53-$ $1.59(\mathrm{~m}, 4 \mathrm{H}), 3.36(\mathrm{t}, 4 \mathrm{H}, \mathrm{J}=6.6 \mathrm{~Hz}), 3.90-3.91(\mathrm{~m}, 4 \mathrm{H}), 5.09-5.12(\mathrm{~m}, 2 \mathrm{H}), 5.18-5.25(\mathrm{~m}, 2 \mathrm{H})$, 5.81-5.90 (m, 2H). ${ }^{13} \mathrm{C}$ NMR $\delta 22.9\left(\mathrm{CH}_{2}\right), 29.6\left(\mathrm{CH}_{2}\right), 70.3\left(\mathrm{CH}_{2}\right), 71.8\left(\mathrm{CH}_{2}\right), 116.7\left(\mathrm{CH}_{2}\right)$, 135.1 (CH). EI-MS (70 eV), m/z (\%) 143 (12), 127 (13), 97 (7), 85 (100), 69 (47), 57 (26).

1,5-Bis(2,3-epoxypropoxy)pentane (5): A solution of $12(0.7 \mathrm{~g}, 3.8 \mathrm{mmol})$ in chloroform (20 $\mathrm{mL})$ was cooled to $0{ }^{\circ} \mathrm{C} .3$-Chloroperbenzoic acid $(\leq 77 \%, 1.96 \mathrm{~g}, 11.4 \mathrm{mmol})$ was added and the mixture was stirred at $0{ }^{\circ} \mathrm{C}$ for $2 \mathrm{~h}$. The mixture was then stirred at room temperature with further additions of 3-chloroperbenzoic acid until the reaction was complete according to TLC. Aqueous $\mathrm{NaOH}(40 \mathrm{~mL})(10 \% \mathrm{w} / \mathrm{v})$ was added and the aqueous phase was extracted with $\mathrm{CH}_{2} \mathrm{Cl}_{2}(40 \mathrm{~mL})$. The organic phase was washed with brine $(40 \mathrm{~mL})$, dried over anhydrous $\mathrm{Na}_{2} \mathrm{SO}_{4}$ and reduced in vacuo. Compound 5 was isolated as a colorless oil $(0.50 \mathrm{~g}, 61 \%)$ after column chromatography (hexane: ethyl acetate, 8:2). ${ }^{1} \mathrm{H}$ NMR $\delta$ 1.35-1.39 (m, 2H), 1.52-1.60 (m, 4H), 2.54-2.56 (m, 2H), 2.73-2.75 (m, 2H), 3.07-3.11 (m, 2H), 3.29-3.33 (m, 2H), 3.39-3.49 $(\mathrm{m}, 4 \mathrm{H}), 3.67(\mathrm{dd}, 2 \mathrm{H}, \mathrm{J}=2.96,11.72 \mathrm{~Hz}) .{ }^{13} \mathrm{C}$ NMR $\delta 22.7,29.5,44.3,50.9,71.5$. EI-MS (70 $\mathrm{eV}), m / z(\%) 143(4), 113(24), 100(5), 85$ (82), 69 (78), 57 (100). 


\section{1,7-Bis(2,3-Epoxypropoxy)heptane (6) (Scheme 2).}

1,7-Bis(allyloxy)heptane (13): Sodium hydride (0.62 g, $26 \mathrm{mmol}, 5.2$ equiv) was washed with hexane $(2 \times 20 \mathrm{~mL})$, suspended in anhydrous THF $(40 \mathrm{~mL})$ and cooled to $0{ }^{\circ} \mathrm{C}$. Heptane-1,7-diol $(0.66 \mathrm{~g}, 5.0 \mathrm{mmol})$ was dissolved in anhydrous THF $(20 \mathrm{~mL})$ and added to the suspension. The mixture was stirred at $0{ }^{\circ} \mathrm{C}$ for $10 \mathrm{~min}$. Allyl bromide $(1.56 \mathrm{~g}, 13 \mathrm{mmol}, 2.6$ equiv) was added and the mixture was stirred at room temperature for $90 \mathrm{~min}$ before refluxing overnight. The reaction was continued until TLC indicated disappearance of the starting material. The mixture was cooled to $0{ }^{\circ} \mathrm{C}$ and saturated aqueous $\mathrm{NH}_{4} \mathrm{Cl}(70 \mathrm{~mL})$ was added slowly to quench the reaction. The aqueous layer was extracted with ethyl acetate $(3 \times 70 \mathrm{~mL})$. The combined organic fractions were washed with brine $(150 \mathrm{~mL})$, dried over anhydrous $\mathrm{Na}_{2} \mathrm{SO}_{4}$ and reduced in vacuo. Compound 13 was obtained as a colorless oil $(0.81 \mathrm{~g}, 76 \%),{ }^{1} \mathrm{H}$ NMR $\delta 1.24-1.36(\mathrm{~m}, 6 \mathrm{H}), 1.51$ $1.57(\mathrm{~m}, 4 \mathrm{H}), 3.38(\mathrm{t}, 4 \mathrm{H}, \mathrm{J}=6.6 \mathrm{~Hz}), 3.91-3.93(\mathrm{~m}, 4 \mathrm{H}), 5.11-5.14(\mathrm{~m}, 2 \mathrm{H}), 5.21-5.26(\mathrm{~m}, 2 \mathrm{H})$, 5.83-5.92 (m, 2H). ${ }^{13} \mathrm{C}$ NMR $\delta 26.2,29.4,29.8,70.5,71.9,116.8,135.1$. EI-MS (70 eV), $\mathrm{m} / \mathrm{z}$ (\%) 171 (19), 125 (5), 113 (21), 97 (65), 81 (17), 71 (42), 55 (100).

1,7-Bis(2,3-epoxypropoxy)heptane (6): A solution of $\mathbf{1 3}(0.8 \mathrm{~g}, 3.8 \mathrm{mmol})$ in chloroform (20 $\mathrm{mL})$ was cooled to $0{ }^{\circ} \mathrm{C}$. 3 -Chloroperbenzoic acid $(\leq 77 \%, 1.96 \mathrm{~g}, 11.4 \mathrm{mmol})$ was added and the mixture was stirred at $0{ }^{\circ} \mathrm{C}$ for $2 \mathrm{~h}$. The mixture was then stirred at room temperature with further additions of 3-chloroperbenzoic acid until the reaction was complete according to TLC. Aqueous $\mathrm{NaOH}(40 \mathrm{~mL})(10 \% \mathrm{w} / \mathrm{v})$ was added and the aqueous phase was extracted with $\mathrm{CH}_{2} \mathrm{Cl}_{2}(40 \mathrm{~mL})$. The organic phase was washed with brine $(40 \mathrm{~mL})$, dried over anhydrous $\mathrm{Na}_{2} \mathrm{SO}_{4}$ and reduced in vacuo. Purification by column chromatography (hexane: ethyl acetate, 8:2) gave 6 as a colorless oil $(0.54 \mathrm{~g}, 58 \%) .{ }^{1} \mathrm{H}$ NMR $\delta$ 1.29-1.32 (m, $\left.6 \mathrm{H}\right), 1.51-1.55(\mathrm{~m}, 4 \mathrm{H})$, 
2.55-2.57 (m, 2H), 2.74-2.76 (m, 2H), 3.07-3.11 (m, 2H), 3.30-3.35 (m, 2H), 3.38-3.48 (m, 4H), 3.64-3.68 (m, 2H). ${ }^{13} \mathrm{C}$ NMR $\delta 26.1,29.3,29.7,44.4,50.9,71.5,71.7$. EI-MS $(70 \mathrm{eV}), \mathrm{m} / z(\%)$ 141 (1), 127 (3), 113 (12), 95 (74), 87 (10), 81 (16), 75 (12), 69 (48), 55 (100).

Experimental Animals. Female CBA/Ca mice, 8 or 9 weeks of age, were purchased from NOVA SCB Charles River, Germany. The mice were housed in "hepa" filtered air flow cages and kept on standard laboratory diet and water ad lib. The local ethics committee in Gothenburg approved the study.

Skin Sensitization Potency of Epoxy Resins in Mice. The local lymph node assay (LLNA) ${ }^{40}$ was used to assess the sensitization potency. Mice in six groups of three animals in each were treated by topical application on the dorsum of both ears with the test compound $(25 \mu \mathrm{L})$ dissolved in acetone:olive oil (AOO) (4:1 v/v) or with the vehicle control. All solutions were freshly prepared for each application. Each compound was tested at five different concentrations. The test concentrations used were as follows: 1 and 2: 1, 5, 10, 20 and 30\% (w/v); Treatments were performed daily for three consecutive days (days 0,1 , and 2). Sham treated control animals received vehicle alone. On day 5 , all mice were injected intravenously via the tail vein with [methyl $-{ }^{3} \mathrm{H}$ ] thymidine $(2.0 \mathrm{Ci} / \mathrm{mmol}$, Amersham Biosciences, UK) $(20 \mu \mathrm{Ci})$ in phosphatebuffered saline (PBS, containing $137 \mathrm{mM} \mathrm{NaCl}, 2.7 \mathrm{mM} \mathrm{KCl}$ and $10 \mathrm{mM}$ phosphate buffer, $\mathrm{pH}$ 7.4) $(250 \mu \mathrm{L})$. After $5 \mathrm{~h}$ the mice were sacrificed, the draining lymph nodes were excised and pooled for each group, and single cell suspensions of lymph-node cells in PBS were prepared using cell strainers (Falcon, BD labware, $70 \mu \mathrm{m}$ pore size). Cell suspensions were washed twice with PBS, precipitated with TCA (5\%) and left in the refrigerator overnight. The samples were 
then centrifuged, resuspended in TCA (5\%) (1 mL) and transferred to a scintillation cocktail (10 mL) (EcoLume, INC Radiochemicals, USA). The [methyl- $\left.{ }^{3} \mathrm{H}\right]$ thymidine incorporation into DNA was measured by $\beta$-scintillation counting on Beckman LS 6000TA Instruments. Results are expressed as mean dpm/lymph node for each experimental group and as stimulation index (SI), i.e., test group/control group ratio. Test materials that at one or more concentrations caused an SI greater than 3 were considered to be positive in the LLNA. EC3 values (the estimated concentration required to induce an SI of 3) were calculated by linear interpolation. The sensitization potency was classified to the following: $\leq 0.2 \% \mathrm{w} / \mathrm{v}$, extreme; $>0.2$ to $\leq 2 \% \mathrm{w} / \mathrm{v}$, strong; $>2 \% \mathrm{w} / \mathrm{v}$ moderate. ${ }^{26}$

KeratinoSens $^{\mathrm{TM}}$ Assay for Sensitization and Cellular Viability. The KeratinoSens ${ }^{\mathrm{TM}}$ assay was performed as previously described in detail. ${ }^{41,42}$ Briefly, cells were grown for $24 \mathrm{~h}$ in 96well plates. The medium was then replaced with medium containing the test chemical and a final level of $1 \%$ DMSO. Each compound was tested at 12 binary dilutions in the range from 0.98 to $2000 \mu$ M. Each test plate contained seven test chemicals, six wells with the solvent control, one well with no cells for background value and five wells with the positive control cinnamic aldehyde in five different concentrations. In each repetition, three parallel replicate plates were run with this same set-up and a fourth parallel plate was prepared for cytotoxicity determination. Cells were incubated for $48 \mathrm{~h}$ with the test agents, after which luciferase activity and cytotoxicity (with the MTT assay ${ }^{43}$ ) were determined. This full procedure was repeated three times for each chemical.

Thiol Reactivity with $\boldsymbol{N}$-Acetyl Cysteine Methyl Ester. Compound DGEBF or 2 (1 mmol) was stirred with $N$-ACME $(1 \mathrm{mmol})$ at $37{ }^{\circ} \mathrm{C}$ overnight in a 2:1 solution of DMSO: ammonium 
acetate buffer (100 mM pH 7.4). The reaction was analyzed using LC/MS (see parameters above).

Reactivity with the Model Peptide Ac-Pro-His-Cys-Lys-Arg-Met-OH (AcPHCKRM). All solvents were degassed with argon prior to use. The hexapeptide AcPHCKRM (Peptide 2.0) was $>99 \%$ pure as determined by HPLC (UV $220 \mathrm{~nm})$. Bz-His-OMe (Bachem) was used as an internal standard. Solutions of PGE, DGEBF or compound 1 in DMSO (40 mM, $100 \mu \mathrm{L})$ together with potassium phosphate buffer $(100 \mathrm{mM}, \mathrm{pH} 7.4),(200 \mu \mathrm{L})$ were added to a vial purged with argon containing AcPHCKRM in DMSO (4 mM, $100 \mu \mathrm{L})$. Accordingly, final concentrations of compound and model peptide in the reaction mixture were $10 \mathrm{mM}$ and $1 \mathrm{mM}$, respectively. The reaction mixture was kept under argon at room temperature and was monitored with $\mathrm{UV}_{210 \mathrm{~nm}} / \mathrm{ESI}-\mathrm{MS}$. As the HPLC run time was 40 minutes, data was combined from two experiments. In the first experiment, samples were collected at $t=0,40,80,120$ mins and in the second experiment at $\mathrm{t}=20,60,100$ mins. In a modified experiment using two haptens simultaneously, $50 \mu \mathrm{L}$ of both PGE and DGEBF $(50 \mathrm{mM})$ were added to the solution containing the peptide, with the other experimental details remaining as above. 


\section{Results and Discussion}

\section{Chemical Synthesis}

Efficient synthetic strategies were employed to produce the biaromatic compounds $\mathbf{1}$ and $\mathbf{2}$ illustrated in Figure 1. A six-step synthesis was used to obtain the non-symmetrical compound $\mathbf{1}$ (Scheme 1, A). 2-Bromoethyl methyl ether and 4-hydroxybenzoic acid were reacted (step $i$ ) and the isolated product 7 was subsequently reacted with $N, O$-dimethylhydroxylamine hydrochloride to produce the Weinreb amide $\mathbf{8}$ (step ii). The amide $\mathbf{8}$ was then coupled to 1-bromo-4-tertbutyldimethylsilyloxybenzene to yield the biaromatic product 9 (step iii). After reduction (step $i v$ ) and deprotection (step $v$ ), the final product 1 was obtained by alkylation of the free phenolic group with epichlorohydrin in $32 \%$ overall yield (step vi).

Synthesis of 2 was achieved in a one-step reaction in a moderate yield of $29 \%$ (Scheme 1, B). The monoalkylated compound was isolated as a by-product. Synthesis of $\mathbf{4}$ was achieved from phenol in $27 \%$ yield (Scheme 1, C). Both 1 and $\mathbf{2}$ were synthesized as tools to investigate the effects of the epoxide functionalities of DGEBF and cannot be used as epoxy resin monomer replacements for polymer synthesis. Compound 1, with one terminal epoxide group and one terminal methoxy group, can only form dimers and compound 2, with two terminal methoxy groups, cannot react with itself or other epoxide-containing polymeric precursors.

Linear compounds $\mathbf{5}$ and $\mathbf{6}$ were synthesized to investigate the influence of sterical shape on the cytotoxicity of 2 . A 5-carbon chain was chosen as it most closely imitates the inter-atomic distance between the two epoxide groups of DGEBF (14.47 $\AA$ for 5 compared to $14.75 \AA$ for DGEBF) (Table S1, Supporting Information). The compound with a 7-carbon chain, 6, was also synthesized to obtain supplemental information. These linear epoxides have greater flexibility 
than DGEBF and hence there are a large number of conformations possible. Compounds 5 and $\mathbf{6}$ were obtained in two steps from 1,5-pentanediol and 1,7-heptanediol, respectively (Scheme 2). The diallylic intermediates $\mathbf{1 2}$ and $\mathbf{1 3}$ were each obtained in 76\% yield by refluxing the starting material with allyl bromide and sodium hydride in an inert atmosphere (step $i$ ). The final compounds are formed by epoxidation using meta-chloroperbenzoic acid (mCPBA) (step ii). The corresponding monoepoxides were observed as by-products.

\section{Skin Sensitization Potency Studies: LLNA and KeratinoSens ${ }^{\mathrm{TM}}$}

Biaromatic compounds $\mathbf{1}$ and $\mathbf{2}$ were assessed in vivo for skin sensitization potency using the murine local lymph node assay (LLNA). ${ }^{44}$ LLNA results are expressed as EC3 values, which is the estimated concentration of a substance required to induce a 3 -fold increase in sensitization compared to a control.

The EC3 value obtained for compound 1 was $74 \mathrm{mM}(2.3 \%$ w/v) (Figure 2 and Table S2, Supporting Information). The stimulation index decreases for the $20 \%$ and $30 \%$ concentrations compared to that of $10 \%$. This effect was seen in repeated LLNA experiments with $\mathbf{1}$. Previously reported LLNA EC3 values for DGEBA, DGEBF and PGE indicate that they are equipotent at $36 \mathrm{mM}, 36 \mathrm{mM}$ and $31 \mathrm{mM}(1.2,1.1$ and $0.46 \% \mathrm{w} / \mathrm{v})$, respectively. ${ }^{21,23}$ According to suggested regulatory classifications, all three are sensitizers of strong potency. ${ }^{26}$ The monoepoxide $\mathbf{1}$ has reduced sensitization potency in the LLNA compared to DGEBF and is classified as a moderate sensitizer according to its EC3 value of $2.3 \%$ w/v. Compound 2 does not contain any reactive epoxide groups and was non-sensitizing in concentrations up to $30 \% \mathrm{w} / \mathrm{v}(950 \mathrm{mM})$ (Figure 2). This compound did not show any dose-response relationship at the concentrations tested. The only structural difference between compound 2 and DGEBF is lack of epoxide groups in 
compound 2 (Figure 1). Thus, our results show that epoxide groups are directly responsible for the skin sensitization effects of DGEBF in the LLNA.

To obtain further information, all compounds were evaluated in the in vitro KeratinoSens ${ }^{\mathrm{TM}}$ assay. ${ }^{42}$ In this assay, compounds are rated as skin sensitizers if they induce the luciferase gene by greater than 1.5 -fold at non-cytotoxic concentrations. Previously published values predict DGEBA, DGEBF and PGE to be sensitizers, giving a 1.5-fold induction at low micromolar concentrations. ${ }^{21}$ The KeratinoSens ${ }^{\mathrm{TM}}$ assay predicts $\mathbf{1}$ as a sensitizer (Table 1). Partial cytotoxicity of a chemical may lead to a luciferase induction in dying cells and therefore chemicals are rated as sensitizers only when luciferase induction starts at non-cytotoxic concentrations. ${ }^{42}$ For compound 2, >1.5-fold induction can only be noted at cytotoxic concentrations, and thus $\mathbf{2}$ is classified as a non-sensitizer by this method. The KeratinoSens ${ }^{\mathrm{TM}}$ results for both biaromatic compounds are in agreement with the LLNA data.

Linear diepoxides 5 and $\mathbf{6}$ were predicted to be sensitizers by the KeratinoSens ${ }^{\mathrm{TM}}$, with maximum induction values $\left(\mathrm{I}_{\max }\right)$ of 209 and 43, respectively. These compounds were not evaluated in the LLNA due to ethical considerations, but it is not surprising that they are predicted to be sensitizers as both contain two terminal, reactive epoxide groups. A structurally related compound, 1,6-hexanediol diglycidyl ether, has a reported EC3 value of $1.9 \% \mathrm{w} / \mathrm{v}$, classifying it as a strong sensitizer. ${ }^{25}$

Two monoaromatic compounds were also assessed in the KeratinoSens ${ }^{\mathrm{TM}}$. Of these, epoxide containing compound 3 was predicted to be a skin sensitizer $\left(I_{\max }=120\right)$, while non-epoxide 4 was predicted as a non-sensitizer ( $\mathrm{I}_{\max }=1.2$ ). Neither $\mathbf{3}$ nor $\mathbf{4}$ were assessed in the LLNA, again due to ethical considerations. On the basis of the results above, $\mathbf{3}$ would be expected to be a 
strong sensitizer in the LLNA due to the presence of the epoxide groups, analogous to PGE. ${ }^{21}$ Conversely, $\mathbf{4}$ is structurally related to $\mathbf{2}$ and would not be expected to act as a sensitizer due to the lack of epoxide groups.

\section{Reactivity Towards the Thiol Residue in Cysteine and in a Model Peptide}

Small molecules react with reactive amino acid residues of proteins in the skin to form immunogenic complexes, which are then recognized by the immune systems as 'non-self' and provoke an immune response. Reactive amino acid residues that play a role in skin sensitization include cysteines (thiol), lysines (amino) and to a lesser extent arginines, histidines, methionines and tyrosines. ${ }^{45}$ It has been previously demonstrated that the epoxy reactive diluent PGE reacts selectively with the thiol residue of a model peptide. ${ }^{23}$ We firstly investigated the reactivity of DGEBF and compound 2 with a cysteine derivative ( $N$-acetyl-L-cysteine methyl ester, $N$ ACME). LC/MS analysis of the DGEBF/ $N$-ACME reaction after 24 hours showed the formation of both monoadducts and diadducts, indicating that DGEBF is thiol-reactive. There was no reaction between $\mathbf{2}$ and $\mathrm{N}$-ACME, indicating that $\mathbf{2}$ is non-reactive towards free thiols. Further reactions of compound $\mathbf{2}$ were not investigated, but we would predict that the methoxy group is also unreactive towards other amino acids implicated in skin sensitization. The results of the reactivity experiment with $N$-ACME indicate that the epoxide groups of DGEBF are necessary for thiol binding.

Having confirmed that the epoxide group was required to react with cysteine, the reactivities of DGEBF, compound $\mathbf{1}$ and PGE towards a model peptide were investigated. The three compounds were chosen to investigate the relative reactivity of a biaromatic diepoxide, a biaromatic monoepoxide and a monoaromatic monoepoxide. The hexapeptide chosen, 
AcPHCKRM, contains both cysteine and lysine amino acid residues. All compounds were stable in the conditions of the assay.

The percentage peptide depletion was calculated for the three compounds (Figure 3 and Table S3, Supporting Information). DGEBF and compound $\mathbf{1}$ are structurally similar with the only difference being one terminal epoxide group in compound $\mathbf{1}$ compared to two in DGEBF. The depletion is slightly faster for DGEBF compared to compound $\mathbf{1}$. The reactivity of DGEBF is similar to that of PGE at $120 \mathrm{~min}$ (7.1\% of free peptide remaining). To confirm the latter result, a second experiment was performed in which both DGEBF and PGE were allowed to react simultaneously with the peptide. $51.5 \%$ of DGEBF-peptide adduct was formed compared to 48.5\% of PGE-peptide adduct, confirming that DGEBF and PGE react with this peptide in essentially equimolar amounts.

Interestingly, the diepoxide DGEBF was observed to only form mono-adducts and did not crosslink peptides. This result is unexpected, as the ability to cross-link proteins could be a potential reason for the enhanced response of DGEBF in the LLNA over compound 1. A potential reason for the lack of cross-linking observed is that an excess of DGEBF compared to peptide is used in this assay $(10: 1$ ratio).

A cysteine adduct was observed for all three compounds, indicated by haptenated y5 and y4 fragments in the MS, but non-haptenated y3 and y2 fragments (Table 2 and Figure S1, Supporting Information). No adducts with lysine or other residues were observed. This is in agreement with previous results showing that the epoxides bind to cysteine residues in peptides. ${ }^{23,46}$ 
In summary, the reactivity experiments indicate that both the biaromatic and monoaromatic epoxide-containing compounds DGEBF, compound 1 and PGE can bind to thiol residues, while compound 2 cannot. This explains the lack of sensitizing effects shown by 2 in the LLNA and KeratinoSens $^{\mathrm{TM}}$.

\section{Cytotoxicity}

All compounds were screened for in vitro cytotoxicity in the KeratinoSens ${ }^{\mathrm{TM}}$ cell line using the MTT assay (Table 1). ${ }^{43}$ The $\mathrm{IC}_{50}$ values for the four biaromatic compounds DGEBA, DGEBF, 1 and 2 fall in the low micromolar range between 22 and $69 \mu \mathrm{M}$. Linear diepoxide 6 (IC $50=169$ $\mu \mathrm{M}$ ) was over 7-fold less cytotoxic compared to both DGEBA and DGEBF. Compound 5 was the least cytotoxic of the epoxide-containing compounds $\left(\mathrm{IC}_{50}=284 \mu \mathrm{M}\right)$. Cytotoxicity of monoaromatic diepoxide $\mathbf{3}\left(\mathrm{IC}_{50}=38 \mu \mathrm{M}\right)$ was in the same range as that of DGEBF, $\mathbf{1}$ and $\mathbf{2}$. The monoepoxide $\mathrm{PGE}$ has an $\mathrm{IC}_{50}$ value of $182 \mu \mathrm{M}$ while compound 4 did not reduce viability by $50 \%$ or more at concentrations up to $2,000 \mu \mathrm{M}$.

DGEBA is known both as an alkylating agent and as a PPAR $\gamma$ antagonist. ${ }^{32,35}$ It is unknown at present if DGEBA covalently modifies the PPAR $\gamma$ receptor. ${ }^{47}$ It is anticipated that DGEBF causes cell death by similar mechanisms to DGEBA due to their structural similarity. The relative loss in cytotoxic potency of the two linear epoxides $\mathbf{5}$ and $\mathbf{6}$ compared to DGEBF may indicate that terminal epoxides are not the only structural feature required for potent cytotoxicity in this cell line. DGEBF and compound $\mathbf{2}$ have equipotent cytotoxicity indicating that a structurally similar compound without reactive epoxides may have a similar cytotoxicity in monolayer cell culture. This is in contrast to the results observed for skin sensitization, where the presence of epoxide groups was essential for sensitizing effects. 
The nature of the alkyl chain has a large impact on in vitro cytotoxicity when comparing monoaromatic compounds PGE and 4. PGE is known to cause cell death via reactive mechanisms, including DNA-damage, ${ }^{48}$ activation of heat shock response and antioxidant response. ${ }^{49}$ PGE forms DNA-adducts via its epoxide group, causing cytotoxicity and apoptosis. Compound 4 lacks the epoxide group, and therefore cannot bind to cellular thiols or cause cell death by reactive mechanisms. Our results indicate that a reactive group is necessary for the cytotoxic effect of the monoaromatic epoxides PGE and $\mathbf{3}$ in the cell line used in our study.

\section{Conclusion}

The aim of our work was to investigate the skin sensitizing potency and in vitro cytotoxicity of analogues of the epoxy resin monomer DGEBF. These results have implications for the development of new ERS components. We have shown that the skin sensitization potency of the epoxy resin monomer DGEBF is due to its terminal epoxide groups. Based on our findings, newly reported epoxy resin monomers ${ }^{50,51}$ would be expected to cause skin sensitization and allergic contact dermatitis as they contain terminal epoxide groups. Our results also imply that there is a need for further research to try to decrease the reactivity of the epoxide groups to a level where the contact sensitization is reduced but the polymerization capacity is still intact. We have shown that the cytotoxicity of DGEBF in monolayer cell culture may not only be dependent

on the epoxide groups. Depending on the structure of alternative epoxy resins, ${ }^{50-52}$ reduced cytotoxicity might be obtained. It is important to keep the potential adverse health effects of epoxy resins in mind when developing a new system and to assess these effects at an early stage in the development process. 
Supporting Information: Inter-atomic distances for linear epoxides and DGEBF, complete LLNA information, results of peptide depletion assays and the structure and fragments of peptide AcPHCKRM are available free of charge via the internet at http://pubs.acs.org.

Funding Support: Financial support for this project was obtained from Swedish Council for Working Life and Social Research and from AFA Försäkring. The work was performed within the Centre for Skin Research at the University of Gothenburg.

Acknowledgements: We would like to acknowledge Daniel Westerberg and Karla Bolbaran for assistance with synthesis, Ida B. Niklasson, Suzanne Exing and Anders Eliasson for assistance with the LLNA experiments and Tina Haupt for KeratinoSens ${ }^{\mathrm{TM}}$ testing. 


\section{References}

(1) Global Industry Analysts, Inc. (2011) Epoxy Resins. A Global Strategic Business Report, pp 1-605, San Jose.

(2) Dickel, H., Kuss, O., Schmidt, A. and Diepgen, T. L. (2002) Occupational relevance of positive standard patch-test results in employed persons with an initial report of an occupational skin disease. Int. Arch. Occup. Environ. Health 75, 423-434.

(3) Condé-Salazar, L., Guimaraens, D., Villegas, C., Rumero, A. and Gonzalez, M. A. (1995) Occupational allergic contact dermatitis in construction workers. Contact Dermatitis 33, 226-230.

(4) Canelas, M. M., Gonçalo, M. and Figueiredo, A. (2010) Contact allergy to epoxy resinsa 10-year study. Contact Dermatitis 62, 55-55.

(5) Pontén, A., Carstensen, O., Rasmussen, K., Gruvberger, B., Isaksson, M. and Bruze, M. (2004) Epoxy-based production of wind turbine rotor blades: occupational dermatoses. Contact Dermatitis 50, 329-338.

(6) Berglind, I. A., Lind, M.-L. and Lidén, C. (2012) Epoxy pipe relining — an emerging contact allergy risk for workers. Contact Dermatitis 67, 59-65.

(7) Majasuo, S., Liippo, J. and Lammintausta, K. (2012) Non-occupational contact sensitization to epoxy resin of bisphenol A among general dermatology patients. Contact Dermatitis 66, 148-153.

(8) Amado, A. and Taylor, J. S. (2008) Contact allergy to epoxy resins. Contact Dermatitis 58, 186-187. 
(9) Andersen, K., White, I. R. and Goossens, A. (2001) Allergens from the Standard Series, In Textbook of Contact Dermatitis (Rycroft, R. J. G., Menne, T. and Frosch, P. J., Eds.), Springer-Verlag, Berlin.

(10) Gamer, A. O., Nies, E. and Vohr, H. W. (2008) Local lymph node assay (LLNA): Comparison of different protocols by testing skin-sensitizing epoxy resin system components. Regul. Toxicol. Pharmacol. 52, 290-298.

(11) Kanerva, L., Jolanki, R. and Estlander, T. (1991) Allergic contact dermatitis from nondiglycidyl-ether-of-bisphenol-A epoxy resins. Contact Dermatitis 24, 293-300.

(12) Kanerva, L., Jolanki, R., Estlander, T., Henriks-Eckerman, M.-L., Tuomi, M.-L. and Tarvainen, K. (2000) Airborne occupational allergic contact dermatitis from triglycidylp-aminophenol and tetraglycidyl-4,4'-methylene dianiline in preimpregnated epoxy products in the aircraft industry. Dermatology 201, 29-33.

(13) Burrows, D., Fregert, S., Campbell, H. and Trulsson, L. (1984) Contact dermatitis from the epoxy resins tetraglycidyl-4,4'-methylene dianiline and $o$-diglycidyl phthalate in composite material. Contact Dermatitis 11, 80-82.

(14) Geier, J., Oestmann, E., Lessmann, H. and Fuchs, T. (2001) Contact allergy to terephthalic acid diglycidylester in a powder coating. Contact Dermatitis 44, 35-36.

(15) Nishioka, K., Ogasawara, M. and Asagami, C. (1988) Occupational contact allergy to triglycidyl isocyanurate (TGIC, Tepic $®)$. Contact Dermatitis 19, 379-380.

(16) Jensen, C. and Andersen, K. (2003) Two cases of occupational allergic contact dermatitis from a cycloaliphatic epoxy resin in a neat oil: Case Report. Environ. Health 2, 3.

(17) Maibach, H. I. and Mathias, C. T. (2001) Allergic contact dermatitis from cycloaliphatic epoxide in jet aviation hydraulic fluid. Contact Dermatitis 45, 56-56. 
(18) Jolanki, R., Kanerva, L., Estlander, T. and Tarvainen, K. (1994) Concomitant sensitization to triglycidyl isocyanurate, diaminodiphenylmethane and 2-hydroxyethyl methacrylate from silk-screen printing coatings in the manufacture of circuit boards. Contact Dermatitis 30, 12-15.

(19) Pontén, A. and Bruze, M. (2001) Contact allergy to epoxy resin based on diglycidyl ether of bisphenol F. Contact Dermatitis 44, 98-100.

(20) Thorgeirsson, A., Fregert, S. and Ramnäs, O. (1978) Sensitization capacity of epoxy resin oligomers in the guinea pig. Acta Derm.-Venereol. 58, 17 - 21.

(21) Delaine, T., Niklasson, I. B., Emter, R., Luthman, K., Karlberg, A.-T. and Natsch, A. (2011) Structure-activity relationship between the in vivo skin sensitizing potency of analogues of phenyl glycidyl ether and the induction of Nrf2-dependent luciferase activity in the KeratinoSens in vitro assay. Chem. Res. Toxicol. 24, 1312-1318.

(22) Pontén, A., Zimerson, E., Sörensen, Ö. and Bruze, M. (2002) Sensitizing capacity and cross-reaction pattern of the isomers of diglycidyl ether of bisphenol $\mathrm{F}$ in the guinea pig. Contact Dermatitis 47, 293-298.

(23) Niklasson, I. B., Broo, K., Jonsson, C., Luthman, K. and Karlberg, A.-T. (2009) Reduced sensitizing capacity of epoxy resin systems: a structure-activity relationship study. Chem. Res. Toxicol. 22, 1787-1794.

(24) Pontén, A., Zimerson, E. and Bruze, M. (2009) Sensitizing capacity and cross-reactivity of phenyl glycidyl ether studied in the guinea-pig maximization test. Contact Dermatitis $60,79-84$. 
(25) Gamer, A. O., Nies, E. and Vohr, H.-W. (2008) Local lymph node assay (LLNA): Comparison of different protocols by testing skin-sensitizing epoxy resin system components. Regul. Toxicol. Pharmacol. 52, 290-298.

(26) Basketter, D. A., Andersen, K. E., Liden, C., Loveren, H. V., Boman, A., Kimber, I., Alanko, K. and Berggren, E. (2005) Evaluation of the skin sensitizing potency of chemicals by using the existing methods and considerations of relevance for elicitation. Contact Dermatitis 52, 39-43.

(27) IARC Monographs Database on Carcinogenic Risks to Humans. http://monographs.iarc.fr/ENG/Classification/index.php Accessed: 07 May 2012.

(28) Deforce, D. L. D., Ryniers, F. P. K., Van den Eeckhout, E. G., Lemiere, F. and Esmans, E. L. (1996) Analysis of DNA adducts in DNA hydrolysates by capillary zone electrophoresis and capillary zone electrophoresis-electrospray mass spectrometry. Anal. Chem. 68, 3575-3584.

(29) Brockmann, W. G., Kostoryz, E. L. and Eick, J. D. (2006) Correlation of apoptotic potential of simple oxiranes with cytotoxicity. Toxicol. In Vitro 20, 729-735.

(30) von der Hude, W., Seelbach, A. and Basler, A. (1990) Epoxides: comparison of the induction of SOS repair in Escherichia coli PQ37 and the bacterial mutagenicity in the Ames test. Mutat. Res., Fundam. Mol. Mech. Mutagen. 231, 205-218.

(31) Greene, E. J., Friedman, M. A., Sherrod, J. A. and Salerno, A. J. (1979) In vitro mutagenicity and cell transformation screening of phenylglycidyl ether. Mutat. Res., Genet. Toxicol. 67, 9-19. 
(32) Hemminki, K., Falck, K. and Vainio, H. (1980) Comparison of alkylation rates and mutagenicity of directly acting industrial and laboratory chemicals. Arch. Toxicol. 46, 277-285.

(33) Cabaton, N., Dumont, C., Severin, I., Perdu, E., Zalko, D., Cherkaoui-Malki, M. and Chagnon, M.-C. (2009) Genotoxic and endocrine activities of bis(hydroxyphenyl)methane (bisphenol F) and its derivatives in the HepG2 cell line. Toxicology 255, 15-24.

(34) Ramilo, G., Valverde, I., Lago, J., Vieites, J. and Cabado, A. (2006) Cytotoxic effects of BADGE (bisphenol A diglycidyl ether) and BFDGE (bisphenol F diglycidyl ether) on Caco-2 cells in vitro. Arch. Toxicol. 80, 748-755.

(35) Wright, H. M., Clish, C. B., Mikami, T., Hauser, S., Yanagi, K., Hiramatsu, R., Serhan, C. N. and Spiegelman, B. M. (2000) A synthetic antagonist for the peroxisome proliferator-activated receptor gamma inhibits adipocyte differentiation. J. Biol. Chem. $275,1873-1877$.

(36) Schaefer, K. L., Takahashi, H., Morales, V. M., Harris, G., Barton, S., Osawa, E., Nakajima, A. and Saubermann, L. J. (2007) PPAR $\gamma$ inhibitors reduce tubulin protein levels by a PPAR $\gamma, \operatorname{PPAR} \delta$ and proteasome-independent mechanism, resulting in cell cycle arrest, apoptosis and reduced metastasis of colorectal carcinoma cells. Int. J. Cancer 120, 702-713.

(37) Bishop-Bailey, D., Hla, T. and Warner, T. D. (2000) Bisphenol A diglycidyl ether (BADGE) is a PPAR $\gamma$ agonist in an ECV304 cell line. Br. J. Pharmacol. 131, 651-654. 
(38) Fehlberg, S., Trautwein, S., Göke, A. and Göke, R. (2002) Bisphenol A diglycidyl ether induces apoptosis in tumour cells independently of peroxisome proliferator-activated receptor-g, in caspase-dependent and -independent manners. Biochem. J. 362, 573-578.

(39) Fehlberg, S., Gregel, C. M., Göke, A. and Göke, R. (2003) Bisphenol A diglycidyl etherinduced apoptosis involves Bax/Bid-dependent mitochondrial release of apoptosisinducing factor (AIF), cytochrome c and Smac/DIABLO. Br. J. Pharmacol. 139, 495500.

(40) Gerberick, G. F., Ryan, C. A., Dearman, R. J. and Kimber, I. (2007) Local lymph node assay (LLNA) for detection of sensitization capacity of chemicals. Methods 41, 54-60.

(41) Natsch, A. and Emter, R. (2008) Skin sensitizers induce antioxidant response element dependent genes: application to the in vitro testing of the sensitization potential of chemicals. Toxicol. Sci. 102, 110-119.

(42) Emter, R., Ellis, G. and Natsch, A. (2010) Performance of a novel keratinocyte-based reporter cell line to screen skin sensitizers in vitro. Toxicol. Appl. Pharmacol. 245, 281290.

(43) Mosmann, T. (1983) Rapid colorimetric assay for cellular growth and survival: Application to proliferation and cytotoxicity assays. J. Immunol. Methods 65, 55-63.

(44) Basketter, D. A., Evans, P., Fielder, R. J., Gerberick, G. F., Dearman, R. J. and Kimber, I. (2002) Local lymph node assay: validation, conduct and use in practice. Food Chem. Toxicol. 40, 593-598.

(45) Divkovic, M., Pease, C. K., Gerberick, G. F. and Basketter, D. A. (2005) Hapten-protein binding: from theory to practical application in the in vitro prediction of skin sensitization. Contact Dermatitis 53, 189-200. 
(46) Niklasson, I. B., Delaine, T., Luthman, K. and Karlberg, A.-T. (2011) Impact of a heteroatom in a structure-activity relationship study on analogues of phenyl glycidyl ether (PGE) from epoxy resin systems. Chem. Res. Toxicol. 24, 542-548.

(47) Elbrecht, A., Chen, Y., Adams, A., Berger, J., Griffin, P., Klatt, T., Zhang, B., Menke, J., Zhou, G., Smith, R. G. and Moller, D. E. (1999) L-764406 is a partial agonist of human peroxisome proliferator-activated receptor-gamma. J. Biol. Chem. 274, 7913-7922.

(48) Fekry, M. I., Price, N. E., Zang, H., Huang, C., Harmata, M., Brown, P., Daniels, J. S. and Gates, K. S. (2011) Thiol-activated DNA damage by alpha-bromo-2-cyclopentenone. Chem. Res. Toxicol. 24, 217-228.

(49) Trott, A., West, J. D., Klaic, L., Westerheide, S. D., Silverman, R. B., Morimoto, R. I. and Morano, K. A. (2008) Activation of heat shock and antioxidant responses by the natural product celastrol: transcriptional signatures of a thiol-targeted molecule. Mol. Biol. Cell 19, 1104-1112.

(50) Cheng, J., Chen, J. and Yang, W. T. (2007) Synthesis and characterization of novel multifunctional epoxy resin. Chin. Chem. Lett. 18, 469-472.

(51) Nouailhas, H., Aouf, C., Le Guerneve, C., Caillol, S., Boutevin, B. and Fulcrand, H. (2011) Synthesis and properties of biobased epoxy resins. part 1. Glycidylation of flavonoids by epichlorohydrin. J. Polym. Sci., Part A: Polym. Chem. 49, 2261-2270.

(52) Kishi, H., Fujita, A., Miyazaki, H., Matsuda, S. and Murakami, A. (2006) Synthesis of wood-based epoxy resins and their mechanical and adhesive properties. J. Appl. Polym. Sci. 102, 2285-2292. 


\section{Tables}

Table 1. Results from the KeratinoSens ${ }^{\mathrm{TM}}$ assay $^{a}$

\begin{tabular}{|c|c|c|c|c|c|}
\hline \multirow[b]{2}{*}{ Compound } & \multicolumn{4}{|c|}{ Luciferase Induction } & \multirow{2}{*}{$\begin{array}{c}\text { Cytotoxicity } \\
\mathrm{IC}_{50}(\mu \mathrm{M})\end{array}$} \\
\hline & $\mathbf{I}_{\max }$ & Classification & $\begin{array}{c}\mathbf{E} C_{K S} 1.5 \\
(\mu M)\end{array}$ & $\begin{array}{c}\mathrm{EC}_{\mathrm{KS}} \mathbf{4 . 5} \\
(\mu \mathrm{M})\end{array}$ & \\
\hline DGEBA $^{21}$ & 13 & Sensitizer & 5.2 & 10 & 22 \\
\hline DGEBF $^{21}$ & 5 & Sensitizer & 6.5 & 12 & 23 \\
\hline $\mathbf{P G E}^{21}$ & 56 & Sensitizer & 16 & 63 & 182 \\
\hline 1 & 76 & Sensitizer & 5.7 & 19 & 69 \\
\hline 2 & $2.2^{b}$ & Non-sensitizer & $9.9^{b}$ & No value & 31 \\
\hline 3 & 120 & Sensitizer & 13 & 16 & 38 \\
\hline 4 & 1.2 & Non-sensitizer & No value & No value & $>2000$ \\
\hline 5 & 209 & Sensitizer & 60 & 105 & 284 \\
\hline 6 & 43 & Sensitizer & 37 & 73 & 169 \\
\hline
\end{tabular}

${ }^{a}$ KeratinoSens $^{\mathrm{TM}}$ assay performed using KeratinoSens ${ }^{\mathrm{TM}}$ reporter keratinocytes, which contain a stable insertion of a luciferase gene under control of the ARE element of the AKR1C2 gene. $\mathrm{I}_{\max }$ is defined as the average maximal induction of gene activity. A luciferase induction of greater than 1.5 -fold at non-cytotoxic concentrations was considered to be significant for skin sensitization. All assays were performed in triplicate on at least 3 separate occasions.

${ }^{b}$ Fold-induction of $>1.5$ was only noted at cytotoxic concentrations; therefore this compound is classified as a nonsensitizer according to the KeratinoSens ${ }^{\mathrm{TM}}$ 
Table 2. Ions and fragments observed in the reactivity experiment with peptide AcPHCKRM ${ }^{a}$

\begin{tabular}{|c|c|c|c|c|c|c|c|}
\hline Hapten & $\begin{array}{c}\text { Molecular } \\
\text { weight }\end{array}$ & $\begin{array}{c}{\left[\mathbf{M}^{*}+\mathbf{H}\right]^{+}} \\
m / z\end{array}$ & $\begin{array}{c}{[\mathbf{M} * \mathbf{+} \mathbf{2 H}]^{2+}} \\
m / z\end{array}$ & $\begin{array}{l}\mathbf{y}_{5}^{*} \\
m / z\end{array}$ & $\begin{array}{l}\mathbf{y}^{*} \\
m / z\end{array}$ & $\begin{array}{c}\mathbf{y}_{3} \\
m / z\end{array}$ & $\begin{array}{l}\mathbf{y}_{2} \\
m / z\end{array}$ \\
\hline DGEBF & 312.4 & 1125.4 & 563.3 & 986.4 & 849.3 & 434.2 & 306.2 \\
\hline 1 & 314.4 & 1127.4 & 564.2 & 988.3 & 851.4 & 434.2 & 306.2 \\
\hline PGE & 150.2 & 963.3 & 482.2 & 824.2 & 687.2 & 434.2 & $\mathrm{Nd}^{b}$ \\
\hline
\end{tabular}

${ }^{a} \mathrm{M}^{*}$ or $\mathrm{y} *$ indicates haptenated peptide or peptide fragment, respectively; $\mathrm{y}$ indicates unhaptenated peptide fragment. The mass of the unhaptenated peptide (M) is 813.2. The masses of the unhaptenated fragments are as follows: y2: 306.2; y3: 434.2; y4: 537.3; y5: 674.3

${ }^{b}$ Not detected. 


\section{Figure Legends}

Figure 1. Structures of DGEBA (diglycidyl ether of bisphenol A), DGEBF (diglycidyl ether of bisphenol F), PGE (phenyl glycidyl ether) and analogues

Figure 2. Local Lymph Node Assay (LLNA) results for DGEBF, 1 and 2. The EC3 value (estimated concentration required to induce a stimulation index (SI) of 3) was calculated using linear interpolation. EC3 values are as follows: DGEBF: $0.036 \mathrm{M}(1.1 \% \mathrm{w} / \mathrm{v}) ;{ }^{21} \mathbf{1}: 0.074 \mathrm{M}(2.3 \% \mathrm{w} / \mathrm{v}) ; 2>0.95 \mathrm{M}(>30$ $\% \mathrm{w} / \mathrm{v})$.

Figure 3. Peptide depletion by DGEBF, 1 and PGE. The model peptide AcPHCKRM was incubated with the relevant compound (1: 10) in a mixture of 1:1 DMSO: potassium phosphate buffer (100 mM, $\mathrm{pH}$ 7.4). The reaction mixture was kept under argon at room temperature and was monitored by UV/ESI-MS. 
Figure 1.<smiles>CC(C)(C)OCc1ccc(C(C)(C)c2ccc(OCC3CO3)cc2)cc1</smiles><smiles>[B-]c1ccc(Cc2ccc(OCC3CO3)cc2)cc1</smiles><smiles>COCCOc1ccc(Cc2ccc(Cc3ccc(OCCOC)cc3)cc2)cc1</smiles><smiles>COCCOc1ccccc1</smiles> 
Figure 2.

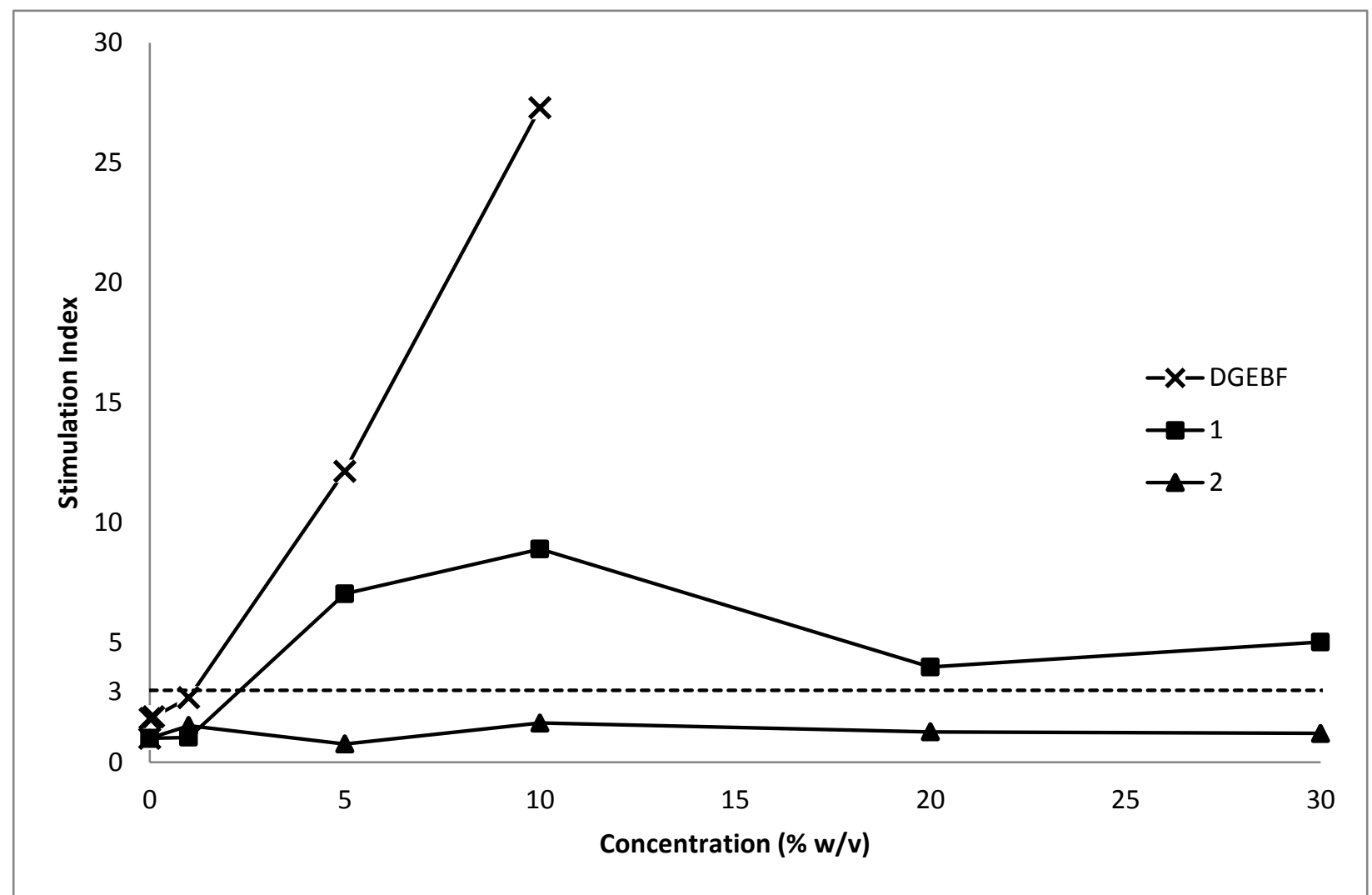


Figure 3.

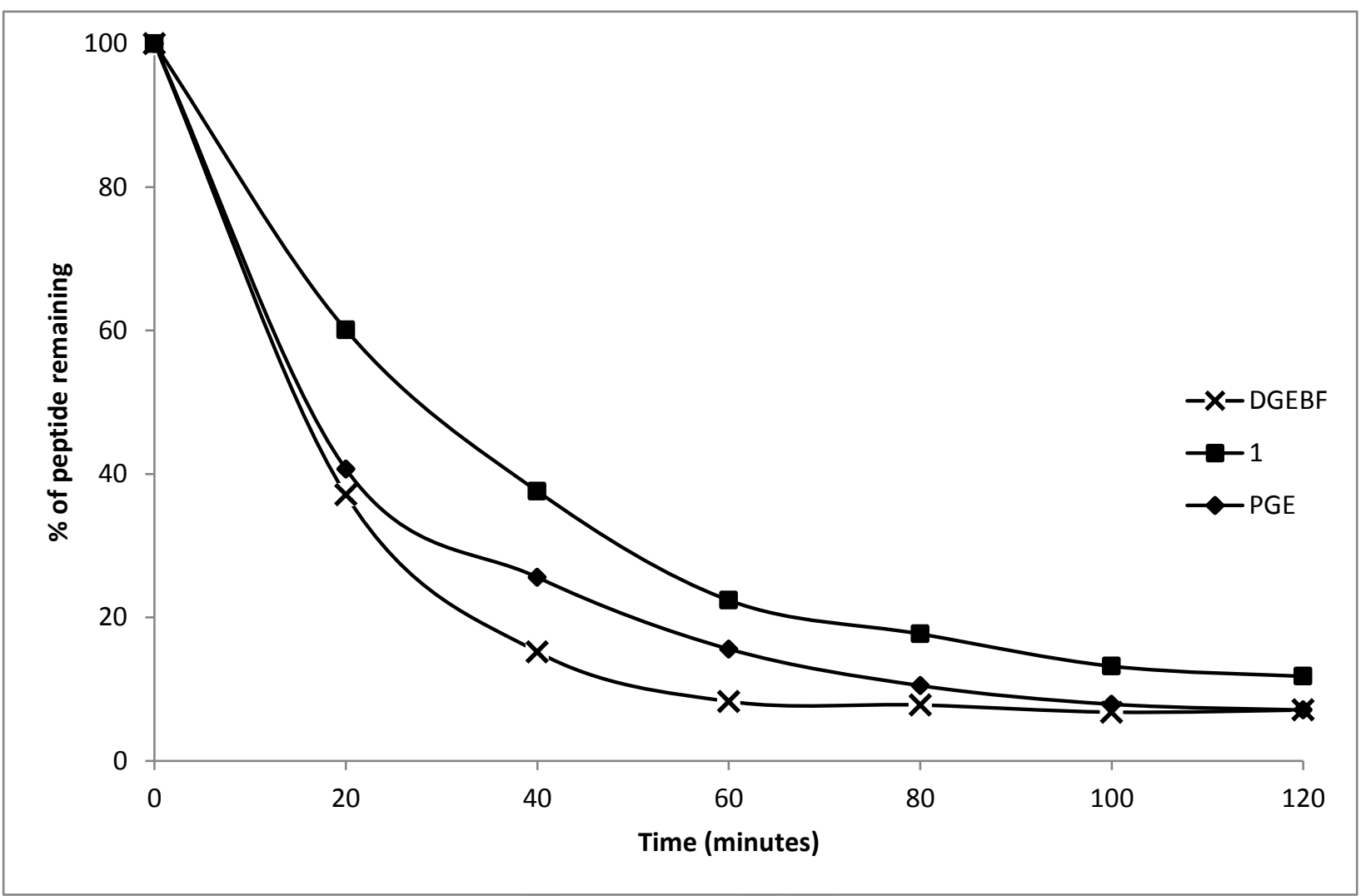




\section{Scheme Legends.}

\section{Scheme 1. Synthesis of compounds 1, 2 and $4^{a}$}

*TBDMS=tert-butyldimethylsilyl

${ }^{a}$ Reagents and conditions: A. (i) $\mathrm{KOH}, \mathrm{EtOH}, \mathrm{N}_{2}, 24 \mathrm{~h}$, reflux; (ii) 4-Methylmorpholine, THF, $-20{ }^{\circ} \mathrm{C}(30 \mathrm{~min}), \mathrm{N}_{2}$, triethylamine, DMF, $0{ }^{\circ} \mathrm{C}(3.5 \mathrm{~h})$; (iii) $\mathrm{C}_{4} \mathrm{H}_{9} \mathrm{Li}$, THF, $\mathrm{N}_{2},-78{ }^{\circ} \mathrm{C}$; (iv) $\mathrm{ZnI}_{2}, \mathrm{NaBH}_{3} \mathrm{CN}, \mathrm{ClCH}_{2} \mathrm{CH}_{2} \mathrm{Cl}, 20 \mathrm{~h}, \mathrm{rt}$; (v) TBAF, THF, $\mathrm{N}_{2}, 3$ h, rt; (vi) $\mathrm{Cs}_{2} \mathrm{CO}_{3}, \mathrm{CH}_{3} \mathrm{CN}, \mathrm{N}_{2}, 3$ h, reflux. B \& C. KOH, EtOH, $\mathrm{N}_{2}, 4$ h, reflux.

\section{Scheme 2. Synthesis of compounds 5 and $6^{a}$}

${ }^{a}$ Reagents and conditions: (i) NaH, THF, $\mathrm{N}_{2}$, reflux, overnight; (ii) $\mathrm{CHCl}_{3}, 0{ }^{\circ} \mathrm{C}$ then RT until complete on TLC 
Scheme 1.

A.<smiles>O=C(O)c1ccc(O)cc1</smiles><smiles>COCCCCC(C)CBr</smiles><smiles>COc1ccc(C(=O)O)cc1</smiles><smiles>[3H][C]CCOC</smiles><smiles>CCCNCC(C)Cl</smiles><smiles>COCCOc1ccc(C(=O)N(C)OC)cc1</smiles><smiles>CC#CCOc1ccc(Cl)cc1</smiles><smiles>COCCOc1ccc(Cc2ccc(O[R16](C)(C)C)cc2)cc1</smiles><smiles>CCCOc1ccc(C(=O)c2ccc(OCC)cc2)cc1</smiles><smiles>COCCOc1ccc(C(c2ccc(O)cc2)C2CC2)cc1</smiles><smiles>C=O</smiles>

10<smiles>CCOc1ccc(Cc2ccc(OCC3CO3)cc2)cc1</smiles>

B.<smiles>COCCOc1ccc(Cc2ccc(OCCOC)cc2)cc1</smiles>

C.<smiles>COC(C)CBr</smiles><smiles>COCCOc1ccccc1</smiles> 
Scheme 2.

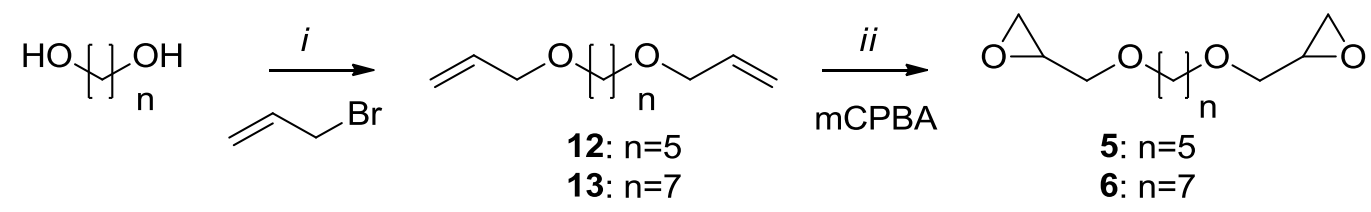

